\title{
Comparison of PD-L1 Assays in Non-small Cell Lung Cancer: 22C3 pharmDx and SP263
}

\author{
DAICHI FUJIMOTO ${ }^{1}$, DAISUKE YAMASHITA ${ }^{2}$, JUNYA FUKUOKA ${ }^{3}$, YUKA KITAMURA ${ }^{3}$, KAZUTAKA HOSOYA ${ }^{1}$, \\ HAYATO KAWACHI ${ }^{1}$, YUKI SATO ${ }^{1}$, KAZUMA NAGATA $^{1}$, ATSUSHI NAKAGAWA ${ }^{1}$, RYO TACHIKAWA $^{1}$, \\ NAOKI DATE ${ }^{4}$, ICHIRO SAKANOUE ${ }^{4}$, HIROSHI HAMAKAWA ${ }^{4}$, YUTAKA TAKAHASHI ${ }^{4}$ and KEISUKE TOMII ${ }^{1}$ \\ ${ }^{1}$ Department of Respiratory Medicine, Kobe City Medical Center General Hospital, Kobe, Japan; \\ ${ }^{2}$ Department of Pathology, Kobe City Medical Center General Hospital, Kobe, Japan; \\ ${ }^{3}$ Department of Pathology, Nagasaki University Graduate School of Biomedical Sciences, Nagasaki, Japan; \\ ${ }^{4}$ Department of Thoracic Surgery, Kobe City Medical Center General Hospital, Kobe, Japan
}

\begin{abstract}
Background/Aim: While the PD-L1 22C3 pharmDx assay is an FDA-approved diagnostic assay for pembrolizumab use, not every pathology laboratory has the Dako Autostainer to use this assay. Since Ventana BenchMark platforms are more common, the Ventana SP263 assay can be used to inform treatment decisions involving nivolumab and pembrolizumab in non-small cell lung cancer (NSCLC). However, some studies have shown discordant results between the two assays. This study aimed was to compare PD-L1 expression using these two assays. Materials and Methods: A total of 100 samples from consecutive cases of resected NSCLC were tested using the two PD-L1 assays. Results: The agreement rates of the two assays were $88-97 \%$ at various cut-offs. There was no significant difference between $22 C 3$ and SP263 in tumour proportion score ( $p=0.455)$. Conclusion: The SP263 assay can be used in the place of the $22 C 3$ assay for PD-L1 testing, for guiding therapy with PD-1 axis inhibitors in NSCLC.
\end{abstract}

Recently, programmed cell death 1 (PD-1)/programmed cell death ligand 1 (PD-L1) inhibitors have demonstrated efficacy in patients with advanced non-small cell lung cancer (NSCLC) (1-3). The identification of patient selection markers for PD-1/PD-L1 inhibitors is critical because of the high treatment costs and potential toxicities associated with these agents. Evidence from clinical trials has revealed that PD-L1 expression on tumour cells (TCs), as assessed by immunohistochemistry (IHC), is a biomarker for predicting the treatment efficacy of immunotherapy $(4,5)$.

Correspondence to: Daichi Fujimoto, MD, Department of Respiratory Medicine, Kobe City Medical Center General Hospital, 2-1-1 Minatojima-Minamimachi, Chuo-ku, Kobe 650-0047, Japan. Tel: +81 783024321, Fax: +81 783027537, e-mail: daichi@kcho.jp

Key Words: PD-1, PD-L1, immunohistochemistry, 22C3, SP263.
Currently, only the PD-L1 IHC 22C3 pharmDx assay, which has been developed for use on the Dako Autostainer, has been approved by the Federal Drug Administration (FDA) as a companion diagnostic assessment for pembrolizumab use. However, not every pathology laboratory has the Dako Autostainer, whereas the Ventana BenchMark platforms are more common in pathology laboratories (6). This represents a major drawback for widespread use of the PD-L1 IHC test in clinical practice. Recently, a fourth antibody, SP263, has been investigated alongside durvalumab for development using the Ventana BenchMark platforms $(7,8)$. In several studies, the $22 \mathrm{C} 3$ assay has shown a high correlation with the SP263 assay (9-14). Thus, the SP263 assay is now Conformité Européeneapproved to inform treatment decisions involving the use of nivolumab and pembrolizumab in NSCLC (15). However, some studies have shown discrepancies in the results of the SP263 and 22C3 assays $(16,17)$.

Thus, in this study, PD-L1 expression results as evaluated by the IHC $22 \mathrm{C} 3$ pharmDx assay on the Dako Autostainer platform were compared with those observed using the SP263 assay on the Ventana BenchMark platform.

\section{Materials and Methods}

Patients and tumour specimens. A total of 100 formalin-fixed, paraffin-embedded (FFPE) samples were collected from consecutive resected lungs with NSCLC at Kobe City Medical Center General Hospital. Specimens were considered adequate for analysis if they were collected within 1 year of PD-L1 staining, as the fading of PDL1 IHC expression has been reported in tissue blocks older than 1 year (18). Specimens diagnosed with adenocarcinoma in situ and minimally invasive adenocarcinoma were excluded.

Patients who reported never having smoked were defined as never smokers, those who had smoked within 1 year of NSCLC diagnosis were categorized as current smokers, and the remaining patients were considered former smokers. All patients were classified on the basis of clinical stage according to the 7th edition TNM classification (19). All tumour specimens included in the 
pathological analysis were obtained with informed consent (or formal waiver of consent) with approval by our Ethics Committee.

Tissue IHC and evaluation. The expression of PD-L1 in NSCLC specimens was analysed with IHC staining using the two assay systems (22C3 and SP263). Sections $4 \mu \mathrm{m}$ thick were cut serially from FFPE tumour blocks and then routinely deparaffinized and rehydrated. For the $22 \mathrm{C} 3$ assay, sections were stained with PD-L1 22C3 mouse monoclonal primary antibodies using the EnVision FLEX visualization system on a Dako Autostainer Link 48 system $(20,21)$. For the SP263 assay, sections were stained with rabbit monoclonal primary antibodies and a matched rabbit immunoglobulin G-negative control, with an OptiView DAB IHC Detection Kit on a BenchMark XT automated staining platform (22). Samples were anonymized, and two pathologists (YK and JF) independently scored all slides, according to the respective scoring algorithms for these assays. TCs were considered PD-L1positive if the cell membrane was partially or completely stained. Cytoplasmic PD-L1 staining in TCs was disregarded, and the staining intensity was not considered. Haematoxylin and eosin (HE) staining was used for each sample to help orient the pathologists when evaluating the IHC slides. The tumour proportion score (TPS) of PDL1 in TCs was expressed as the percentage of PD-L1-positive TCs in the overall tumour section and was estimated in increments of 5\%, except in the case of $1 \%$ positivity. In the case of a disagreement, the slides were re-examined until a consensus was reached.

Several cut-offs related to the levels of PD-L1 expression have been used in clinical trials $(3,7,23)$. Cut-off values of $1 \%, 25 \%$, and $50 \%$ were set according to the values used in prospective clinical trials of PD-1 axis inhibitors.

Statistical analysis. Concordance between assays was evaluated using the overall percentage of agreement (OPA) related to specific thresholds. OPAs were determined according to the $1 \%, 25 \%$, and $50 \%$ thresholds. The Wilcoxon signed rank test was used to evaluate differences in TPS. To evaluate the distribution of each monoclonal antibody polynomial trend curves were used. Statistical analyses were conducted using JMP 11 software (SAS Institute, Cary, NC, USA).

\section{Results}

A total of 99 specimens were considered adequate for analysis, whereas one specimen did not contain enough TCs. Patient characteristics are summarized in Table I. Most patients $(74 \%)$ had stage I NSCLC. Their mean age was 71.3 years, and $72(73 \%)$ patients had adenocarcinoma histology. The interobserver concordance in the scoring of PD-L1positive carcinoma cells was assessed (Table II). Good agreement between the two pathologists was observed. In both assays, the OPAs at the PD-L1 expression cut-offs of $1 \%, 25 \%$, and $50 \%$ were $>90 \%$.

The concordance rates for the 22C3 and SP263 assays based on the consensus TPS as determined by two pathologists are shown in Table III. The distributions of IHC intensities stratified by the three cut-offs $(1 \%, 25 \%$, and $50 \%$ ) were analysed. The OPAs at the $1 \%, 25 \%$, and $50 \%$ cut-offs were $88 \%, 94 \%$, and $97 \%$, respectively. There was no significant difference between 22C3 and SP263 in actual TPS (median (interquartile range): 0 (0-30\%) vs. 0 (0-20\%),
Table I. Patient characteristics.

\begin{tabular}{lc}
\hline Patient characteristics & $\mathrm{n}(\%)$ \\
& $(\mathrm{N}=99)$ \\
\hline Age (years) & \\
Mean (SD) & $71.3(9.7)$ \\
Gender & \\
Male & $63(64)$ \\
Female & $36(36)$ \\
Smoking status & \\
Never & $33(33)$ \\
Current or former & $66(67)$ \\
Histology & \\
Adenocarcinoma & $72(73)$ \\
Squamous cell carcinoma & $18(18)$ \\
Others & $9(9)$ \\
Stage & \\
I & $73(74)$ \\
II & $15(15)$ \\
III & $10(10)$ \\
IV & $1(1)$ \\
\hline
\end{tabular}

SD: Standard deviation.

Table II. Comparison of PD-L1 TPS by several cut-offs.

\begin{tabular}{lrrcr}
\hline $22 \mathrm{C} 3$ & \multicolumn{4}{c}{ Pathologist B } \\
\cline { 2 - 5 } Pathologist A & $<1$ & $1-24$ & $25-49$ & $\geq 50$ \\
\hline$<1$ & 44 & 1 & 0 & 0 \\
$1-24$ & 6 & 20 & 1 & 0 \\
$25-49$ & 0 & 4 & 3 & 1 \\
$\geq 50$ & 0 & 0 & 1 & 18 \\
\hline
\end{tabular}

Concordant pairs: 0.86 (85/99); Pathologist A higher: 0.11 (11/99); Pathologist B higher: 0.03 (3/99); Agreement (1\%, 25\%, 50\%): 93\%, $95 \%, 98 \%$.

\begin{tabular}{lrrrr}
\hline SP263 & \multicolumn{4}{c}{ Pathologist B } \\
\cline { 2 - 5 } Pathologist A & $<1$ & $1-24$ & $25-49$ & $\geq 50$ \\
\hline$<1$ & 46 & 1 & 0 & 0 \\
$1-24$ & 3 & 26 & 2 & 1 \\
$25-49$ & 0 & 0 & 2 & 1 \\
$\geq 50$ & 0 & 0 & 2 & 15 \\
\hline
\end{tabular}

Concordant pairs: 0.90 (89/99); Pathologist A higher: 0.05 (5/99); Pathologist B higher: 0.05 (5/99); Agreement (1\%, 25\%, 50\%): 96\%, 97\%, 96\%. PD-L1: Programmed cell death ligand 1; TPS: tumor proportion score.

$p=0.455$ ). Specifically, for 22C3 and SP263, 51\% and 50\% of patients were negative (TPS $<1 \%$ ), respectively; $23 \%$ and $28 \%$ had TPS values of $1-24 \%$, respectively; $7 \%$ and $5 \%$ had TPS values of $25-49 \%$, respectively; and $19 \%$ and $17 \%$ were strongly positive (TPS $\geq 50 \%$ ), respectively. The distributions 


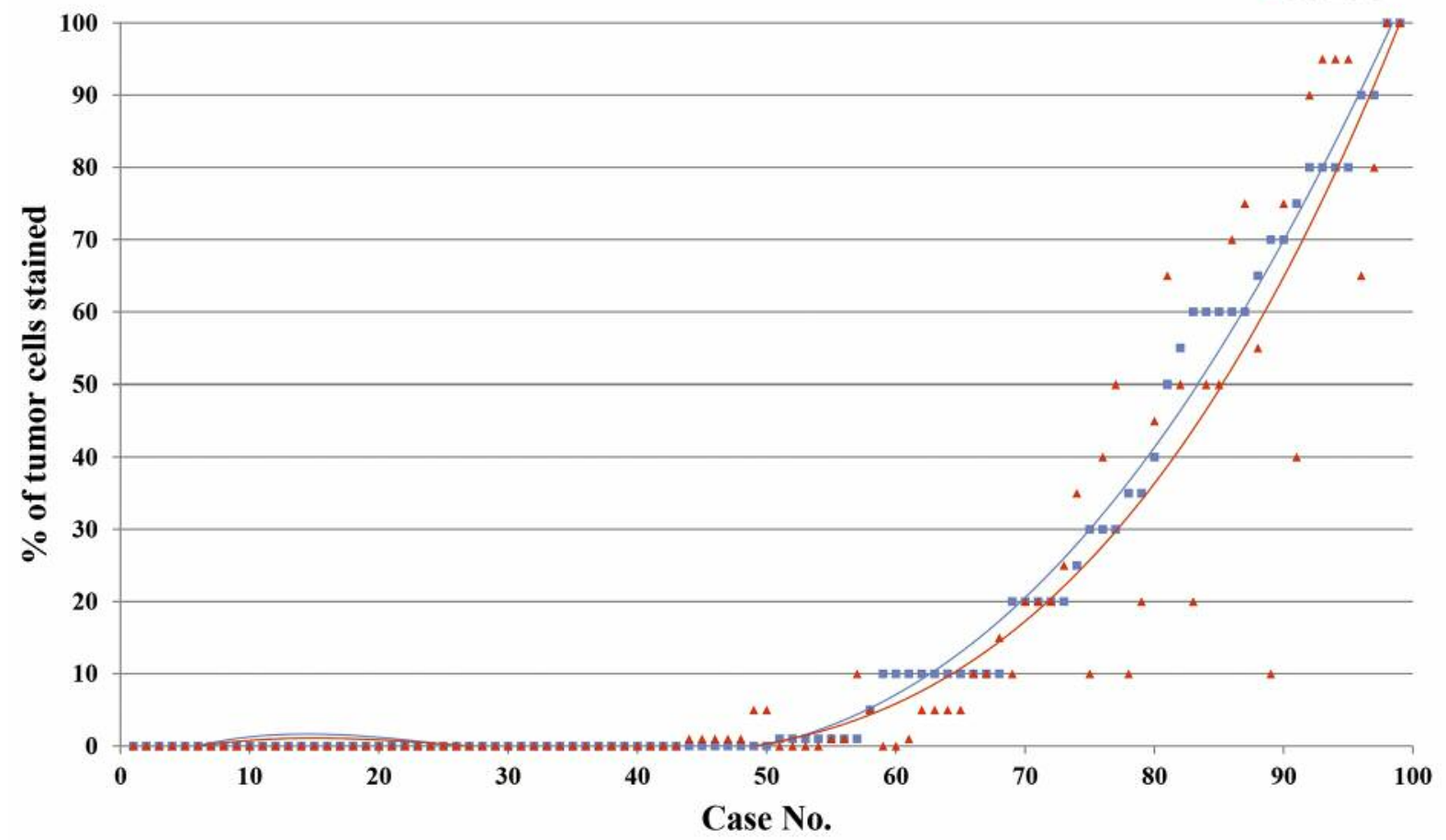

Figure 1. Analytical comparison of TPS values by case after analysis with each assay.

of the TC staining percentage for each assay, as agreed upon by two pathologists, are shown in Figure 1.

Twenty-one cases exhibited discordant results between the 22C 3 and SP263 assays. Of these, 19 cases exhibited similar values between the two assays but were assigned different categories as the values were near the cut-off point. Of the 21 discordant cases, 13 were negative $(<1 \%)$ according to one assay of the two assays used. Of these 13 specimens, all exhibited TPS values of between 1 and $10 \%$ in the positive assay. In addition, four were considered discordant, as these cases exhibited TPS values of $1-24 \%$ in one assay but $25-49 \%$ in the other assay. Furthermore, four were strongly positive $(\geq 50 \%)$ in one assay but not both. In these four cases, the TPS values according to the $223 \mathrm{C}$ and SP263 assays were $75 \%$ and $40 \%, 70 \%$ and $10 \%$, $60 \%$ and $20 \%$, and $30 \%$ and $50 \%$, respectively.

\section{Discussion}

This study compared two PD-L1 IHC assay systems. A high correlation between PD-L1 IHC expression results obtained with the 22C3 and SP263 tests in NSCLC were found.

Administration of pembrolizumab in particular, requires the use of the FDA-approved companion diagnostic 22C3 assay on the Dako Autostainer Link 48. However, this may not be practical in many pathology laboratories for various reasons,
Table III. Comparison of PD-L1 TPS by several cut-offs.

\begin{tabular}{lrrcc}
\hline \multicolumn{5}{c}{ SP263 } \\
\cline { 2 - 5 } $22 \mathrm{C} 3$ & $<1$ & $1-24$ & $25-49$ & $\geq 50$ \\
\hline$<1$ & 43 & 7 & 0 & 0 \\
$1-24$ & 6 & 16 & 1 & 0 \\
$25-49$ & 0 & 3 & 3 & 1 \\
$\geq 50$ & 0 & 2 & 1 & 16 \\
\hline
\end{tabular}

Concordant pairs: 0.79 (78/99); SP263 higher: 0.09 (9/99); 22C3 higher: 0.12 (12/99); Agreement $(1 \%, 25 \%, 50 \%): 88 \%, 94 \%, 97 \%$. PD-L1: Programmed cell death ligand 1; TPS: tumor proportion score.

including the unavailability of the specified platform and the availability, instead ,of other platforms (24). For this reason, demonstration of the utility of the Ventana system is needed in clinical settings. At present, the PD-L1 IHC assays with SP142 and SP263 require the use of Ventana platforms. However, previous studies have shown that the SP142 assay is an outlier among PD-L1 assays (10-12). Thus, the concordance between the 22C3 and SP263 assays is important.

In our study, the distributions of PD-L1 status as assessed by the $22 \mathrm{C} 3$ assay were slightly different from those reported in clinical trials $(3,25)$. However, PD-L1 expression is lower 
in patients with early-stage NSCLC than in those with advanced stage disease $(26,27)$. Considering these findings and our present data, the staining results of $22 \mathrm{C} 3$ were concordant with previous results.

Our data indicate a high analytical correlation between the expression results obtained by the two different commercially available PD-L1 assays. At a cut-off of 50\% or higher, which is used for the selection of patients for first-line treatment with pembrolizumab, the OPA was $97 \%$ between the $22 \mathrm{C} 3$ and SP263 assays. Additionally, the OPA at a cut-off of $1 \%$ or higher was also near $90 \%$. In our cohort, there were 21 discordant cases out of 99 cases using cut-offs of 1,25 , and $50 \%$. Of these 21 discordant cases, 19 exhibited values in the two assays that were close but were around one of the cut-off points. Therefore, the actual TPS values of most discordant cases were similar between the two assays.

Consistent with our results, in several studies, the results of the 22C3 assay have shown a high correlation with those of the SP263 assay (9-14). However, some studies have shown high rates of discordant results between the SP263 and 22C3 assays $(16,17)$. The precise reason for these discrepancies is unclear. There are various possible explanations, such as tumour heterogeneity, the number of TCs in the specimen, variability in the performance of the staining platform, and variability in the performance of the observer. In a previous study reporting discordant results between the 22C3 and SP263 assays, interobserver agreement appeared to be lower than that in our study (16). Additionally, another discordant study cohort consisted of tissue microarrays constructed from two patient cohorts (17). In this study, TCs were scored if a minimum of 50 viable TCs were present, although 100 viable cells is considered appropriate in clinical settings. According to a previous study that compared the performances of the $22 \mathrm{C} 3$ and SP263 assays (9), discordant results were more common from small biopsy samples. Therefore, further study is needed to investigate the characteristics of the differences between discordant and concordant specimens.

Our study has certain limitations. First, this was a retrospective, single-centre study with a small number of Japanese patients. Second, we used only surgical specimens in this study and only analyzed concordance in those with an adequate number of TCs. However, as mentioned, discordant results may be more common among small biopsy samples (9).

In conclusion, on the basis of this study and previous studies, the SP263 assay could be used in place of the 22C3 assay for PD-L1 testing for the purposes of guiding therapy with anti-PD-1/PD-L1 in NSCLC.

\section{Acknowledgements}

The Authors would like to thank Keiichiro Uehara, Yukihiro Imai, Kaori Shimoda and Yuki Imaoka for their contributions to the pathological analysis, and Hideshi Imoto, Keiko Sakuragawa, and
Ayako Okamoto for administrative assistance.This study was supported by internal funding and the Ethics Committee of Kobe City Medical Center General Hospital and AstraZeneca.

\section{Conflicts of Interest}

Dr. Fujimoto has received lecture fees from Ono Pharmaceutical Co., Ltd., Bristol-Myers Squibb K.K., Chugai Pharmaceutical, AstraZeneca, Merck Sharp and Dohme, and Taiho Pharmaceutical. Dr. Sato has received lecture fees from Ono Pharmaceutical Co., Ltd. Dr. Kitamura is the CEO of N Lab Co., Ltd and its stockholder. Dr. Tomii has received lecture fees from Chugai Pharmaceutical, AstraZeneca, and Taiho Pharmaceutical. The remaining authors declare no conflict of interest.

\section{References}

1 Borghaei H1, Paz-Ares L, Horn L, Spigel DR, Steins M, Ready NE, Chow LQ, Vokes EE, Felip E, Holgado E, Barlesi F, Kohlhäufl M, Arrieta $\mathrm{O}$, Burgio MA, Fayette J, Lena H, Poddubskaya E, Gerber DE, Gettinger SN, Rudin CM, Rizvi N, Crinò L, Blumenschein GR Jr., Antonia SJ, Dorange C, Harbison $\mathrm{CT}$, Graf Finckenstein $\mathrm{F}$ and Brahmer JR: Nivolumab versus docetaxel in advanced non-squamous non-small-cell lung cancer. N Engl J Med 373: 1627-1639, 2015.

2 Brahmer J, Reckamp KL, Baas P, Crinò L, Eberhardt WE, Poddubskaya E, Antonia S, Pluzanski A, Vokes EE, Holgado E, Waterhouse D, Ready N, Gainor J, Arén Frontera O, Havel L, Steins M, Garassino MC, Aerts JG, Domine M, Paz-Ares L, Reck M, Baudelet C, Harbison CT, Lestini B and Spigel DR: Nivolumab versus docetaxel in advanced squamous-cell nonsmall-cell lung cancer. N Engl J Med 373: 123-135, 2015.

3 Herbst RS, Baas P, Kim DW, Felip E, Pérez-Gracia JL, Han JY, Molina J, Kim JH, Arvis CD, Ahn MJ, Majem M, Fidler MJ, de Castro G Jr, Garrido M, Lubiniecki GM, Shentu Y, Im E, Dolled-Filhart $\mathrm{M}$ and Garon $\mathrm{EB}$ : Pembrolizumab versus docetaxel for previously treated, PD-L1-positive, advanced nonsmall-cell lung cancer (KEYNOTE-010): a randomised controlled trial. Lancet 387: 1540-1550, 2016.

4 Carbognin L, Pilotto S, Milella M, Vaccaro V, Brunelli M, Calio A, Cuppone F, Sperduti I, Giannarelli D, Chilosi M, Bronte V, Scarpa A, Bria E and Tortora G: Differential activity of nivolumab, pembrolizumab and MPDL3280A according to the tumor expression of programmed death-ligand-1 (PD-L1): sensitivity analysis of trials in melanoma, lung and genitourinary cancers. PLoS One 10: e0130142, 2015.

5 Abdel-Rahman O: Correlation between PD-L1 expression and outcome of NSCLC patients treated with anti-PD-1/PD-L1 agents: A meta-analysis. Crit Rev Oncol Hematol 101: 75-85, 2016.

6 Neuman T, London M, Kania-Almog J, Litvin A, Zohar Y, Fridel L, Sandbank J, Barshak I and Vainer GW: A harmonization study for the use of 22C3 PD-L1 immunohistochemical staining on Ventana's platform. J Thorac Oncol 11: 1863-1868, 2016.

7 Garassino MC, Cho BC, Kim JH, Mazières J, Vansteenkiste J, Lena H, Corral Jaime J, Gray JE, Powderly J, Chouaid C, Bidoli P, Wheatley-Price P, Park K, Soo RA, Huang Y, Wadsworth C, Dennis PA and Rizvi NA; ATLANTIC Investigators: Durvalumab as third-line or later treatment for advanced nonsmall-cell lung cancer (ATLANTIC): an open-label, single-arm, phase 2 study. Lancet Oncol 19: 521-536, 2018. 
8 Antonia SJ, Villegas A, Daniel D, Vicente D, Murakami S, Hui R, Yokoi T, Chiappori A, Lee KH, de Wit M, Cho BC, Bourhaba M, Quantin X, Tokito T, Mekhail T, Planchard D, Kim YC, Karapetis CS, Hiret S, Ostoros G, Kubota K, Gray JE, Paz-Ares L, de Castro Carpeño J, Wadsworth C, Melillo G, Jiang H, Huang Y, Dennis PA and Özgüroğlu M; PACIFIC Investigators: Durvalumab after chemoradiotherapy in stage III non-small-cell lung cancer. N Engl J Med 377: 1919-1929, 2017.

9 Sughayer MA, Alnaimy F, Alsughayer AM and Qamhia N: Comparison of $22 \mathrm{C} 3$ pharmDx and SP263 assays to test PD-L1 expression in NSCLC. Appl Immunohistochem Mol Morphol, 2018. doi:10.1097/PAI.0000000000000671. [Epub ahead of print]

10 Tsao MS, Kerr KM, Kockx M, Beasley MB, Borczuk AC, Botling J, Bubendorf L, Chirieac L, Chen G, Chou TY, Chung JH, Dacic S, Lantuejoul S, Mino-Kenudson M, Moreira AL, Nicholson AG, Noguchi M, Pelosi G, Poleri C, Russell PA, Sauter J, Thunnissen E, Wistuba I, Yu H, Wynes MW, Pintilie M, Yatabe Y and Hirsch FR: PD-11 immunohistochemistry comparability study in real-life clinical samples: results of blueprint phase 2 project. J Thorac Oncol 13: 1302-1311, 2018

11 Hirsch FR, McElhinny A, Stanforth D, Ranger-Moore J, Jansson M, Kulangara K, Richardson W, Towne P, Hanks D, Vennapusa B, Mistry A, Kalamegham R, Averbuch S, Novotny J, Rubin E, Emancipator K, McCaffery I, Williams JA, Walker J, Longshore J, Tsao MS and Kerr KM: PD-L1 immunohistochemistry assays for lung cancer: results from phase 1 of the blueprint PD-L1 IHC assay comparison project. J Thorac Oncol 12: 208-222, 2017.

12 Fujimoto D, Sato Y, Uehara K, Ishida K, Fukuoka J, Morimoto T, Kawachi H, Mori R, Ito M, Teraoka S, Nagata K, Nakagawa A, Otsuka K, Imai Y and Tomii K: Predictive performance of four programmed cell death ligand 1 assay systems on nivolumab response in previously treated patients with non-small cell lung cancer. J Thorac Oncol 13: 377-386, 2018.

13 Ratcliffe MJ, Sharpe A, Midha A, Barker C, Scott M, Scorer P, Al-Masri H, Rebelatto MC and Walker J: Agreement between programmed cell death ligand-1 diagnostic assays across multiple protein expression cutoffs in non-small cell lung cancer. Clin Cancer Res 23: 3585-3591, 2017.

14 Marchetti A, Barberis M, Franco R, De Luca G, Pace MV, Staibano S, Volante M, Buttitta F, Guerini-Rocco E, Righi L, D'antuono T, Scagliotti GV, Pinto C, De Rosa G and Papotti M: Multicenter comparison of 22C3 pharmDx (Agilent) and SP263 (Ventana) assays to test PD-L1 expression for NSCLC patients to be treated with immune checkpoint inhibitors. J Thorac Oncol 12: 1654-1663, 2017.

15 Roche. Roche's VENTANA PD-L1 (SP263) assay. https:// diagnostics.roche.com/global/en/products/tests/ventana-pd-11_sp263-assay2.html. (Accessed August 11 2018).

16 Munari E, Rossi G, Zamboni G, Lunardi G, Marconi M, Sommaggio M, Netto GJ, Hoque MO, Brunelli M, Martignoni G, Haffner MC, Moretta F, Pegoraro MC, Cavazza A, Samogin G, Furlan V, Mariotti FR, Vacca P, Moretta L and Bogina G: PDL1 assays 22C3 and SP263 are not interchangeable in non-small cell lung cancer when considering clinically relevant cutoffs: an interclone evaluation by differently trained pathologists. Am J Surg Pathol 42: 1384-1389, 2018.

17 Hendry S, Byrne DJ, Wright GM, Young RJ, Sturrock S, Cooper WA and Fox SB: Comparison of four PD-L1 immunohistochemical assays in lung cancer. J Thorac Oncol 13: 367-376, 2018.

18 Giunchi F, Degiovanni A, Daddi N, Trisolini R, Dell'Amore A, Agostinelli C, Ardizzoni A and Fiorentino M: Fading with time of PD-L1 immunoreactivity in non-small cells lung cancer tissues: a methodological study. Appl Immunohistochem Mol Morphol 26: 489-494, 2018.

19 Goldstraw P, Crowley J, Chansky K, Giroux DJ, Groome PA, Rami-Porta R, Postmus PE, Rusch V and Sobin L; International Association for the Study of Lung Cancer International Staging Committee; Participating Institutions: The IASLC Lung Cancer Staging Project: proposals for the revision of the TNM stage groupings in the forthcoming (seventh) edition of the TNM Classification of malignant tumours. J Thorac Oncol 2: 706-714, 2007.

20 Phillips T, Simmons P, Inzunza HD, Cogswell J, Novotny J Jr, Taylor $\mathrm{C}$ and Zhang X: Development of an automated PD-L1 immunohistochemistry (IHC) assay for non-small cell lung cancer, Appl Immunohistochem Mol Morphol 23: 541-549, 2015.

21 Roach C, Zhang N, Corigliano E, Jansson M, Toland G, Ponto G, Dolled-Filhart M, Emancipator K, Stanforth D and Kulangara $\mathrm{K}$ : Development of a companion diagnostic PD-L1 immunohistochemistry assay for pembrolizumab therapy in non-smallcell lung cancer. Appl Immunohistochem Mol Morphol 24: 392397, 2016.

22 Rebelatto MC, Midha A, Mistry A, Sabalos C, Schechter N, Li $\mathrm{X}$, Jin X, Steele KE, Robbins PB, Blake-Haskins JA and Walker $\mathrm{J}$ : Development of a programmed cell death ligand-1 immunohistochemical assay validated for analysis of non-small cell lung cancer and head and neck squamous cell carcinoma. Diagn Pathol 11: 95, 2016.

23 Reck M, Rodríguez-Abreu D, Robinson AG, Hui R, Csőszi T, Fülöp A, Gottfried M, Peled N, Tafreshi A, Cuffe S, O'Brien M, Rao S, Hotta K, Leiby MA, Lubiniecki GM, Shentu Y, Rangwala $\mathrm{R}$ and Brahmer JR; KEYNOTE- Investigators: Pembrolizumab versus chemotherapy for PD-L1-positive nonsmall-cell lung cancer. N Engl J Med 375: 1823-1833, 2016.

24 Adam J, Le Stang N, Rouquette I, Cazes A, Badoual C, PinotRoussel H, Tixier L, Danel C, Damiola F, Damotte D, PenaultLlorca $\mathrm{F}$ and Lantuéjoul S: Multicenter harmonization study for PD-L1 IHC testing in non-small-cell lung cancer. Ann Oncol 29: 953-958, 2018.

25 Garon EB, Rizvi NA, Hui R, Leighl N, Balmanoukian AS, Eder JP, Patnaik A, Aggarwal C, Gubens M, Horn L, Carcereny E, Ahn MJ, Felip E, Lee JS, Hellmann MD, Hamid O, Goldman JW, Soria JC, Dolled-Filhart M, Rutledge RZ, Zhang J, Lunceford JK, Rangwala R, Lubiniecki GM, Roach C, Emancipator K and Gandhi L; KEYNOTE-001 Investigators: Pembrolizumab for the treatment of non-small-cell lung cancer. N Engl J Med 372: 2018-2028, 2015.

26 Fujimoto D, Sato Y, Morimoto T, Uehara K, Ito M, Otsuka K, Nagata K, Sakanoue I, Hamakawa H, Nakagawa A, Takahashi Y, Imai $\mathrm{Y}$ and Tomii $\mathrm{K}$ : Programmed cell death ligand 1 expression in non-small-cell lung cancer patients with interstitial lung disease: a matched case-control study. Clin Lung Cancer 19: e667-e673, 2018.

27 Tsao MS, Le Teuff G, Shepherd FA, Landais C, Hainaut P, Filipits M, Pirker R, Le Chevalier T, Graziano S, Kratze R, Soria JC, Pignon JP, Seymour L and Brambilla E: PD-L1 protein expression assessed by immunohistochemistry is neither prognostic nor predictive of benefit from adjuvant chemotherapy in resected nonsmall cell lung cancer. Ann Oncol 28: 882-889, 2017.

Received November 2, 2018

Revised November 7, 2018

Accepted November 8, 2018 